\title{
OBITUARY
}

\section{Harold James Mons Duncan, 1929 - 2017}

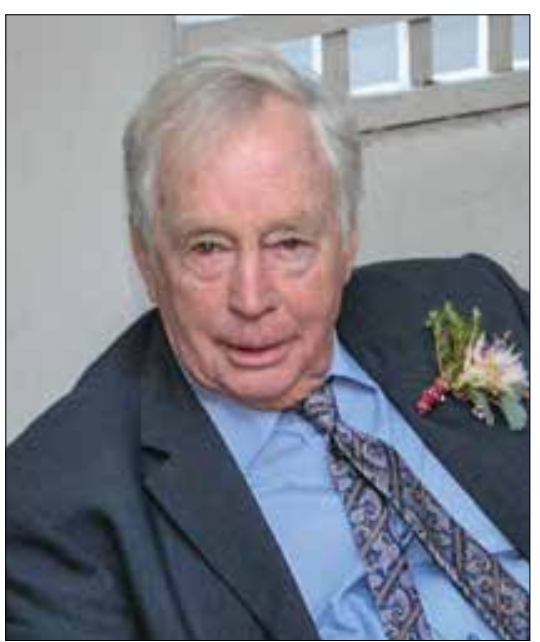

I report with much sadness that my great friend and erstwhile partner, the excellent surgeon Harold Duncan, has passed away.

Harold was born and spent his childhood in the West Springs Mine area (as did my wife, whom he used to refer to jokingly as his oldest girlfriend). He matriculated at King Edward VII School, where he was a boarder, qualified $\mathrm{MB} \mathrm{BCh}$ at the University of the Witwatersrand in 1952, and completed his internship in Kroonstad, where he came under the tuition of the legendary surgeon Prof. Chris Derksen. A later mentor was another excellent surgeon, Prof. Dick Schulenburg, in Pretoria.

While in Kroonstad Harold did locums for Dr Alf Robertson, who subsequently moved to Durban, where he built up a shipping practice that was not only successful but required skill in various languages as well as good judgement. Knowing Harold well, Alf referred much of this work to him when Harold joined the practice of Mannie Stein, who had introduced vascular surgery in Natal. Mannie was a very bold surgeon, and I joined him in practice in 1963. Harold and I had a wonderful working relationship, covering each other's work on Wednesdays and Thursdays so that we could play golf. We shared the railway and harbour intake, working on alternate weeks. The practice was very busy, and we were never short of operating experience.

Harold rented a house in Plettenberg Bay, which he subsequently bought, and this changed the lives of his family. He was very generous in allowing us to use it as often as we liked. It was a lovely home, overlooking Outlook Beach and surrounded by rock pools, with a viewing point from which one could watch dolphins cavorting in the deep blue sea. He would leave Durban early in the morning and drive straight through to reach this home ten hours later.

Harold was a mean golfer, but as a result of locomotor problems due to an arthrodesis of his ankle followed by a rupture of the tibialis anterior, he changed to bowls and thoroughly enjoyed the social mix of his fellow bowlers. He was also a prominent member of the Durban Discussion Group, which invited experts in their fields to give talks every month. Always popular and always modest, he had a spontaneous and cutting sense of humour, but was never cruel.

Harold's lovely wife Pam died in 2004 from a highly malignant ovarian tumour, after which he spent time living with his children and grandchildren in Durban. $\mathrm{He}$ was then fortunate to find companionship with Mary Ross, a widow, and they lived alternately in Stellenbosch on a wine farm and in Plettenberg Bay.

He will be sorely missed by his children, Peter, Ann and Janet, and his grandchildren.

\section{Roy Wise}

Durban, South Africa

wisel@mweb.co.za 